\title{
Simultaneous Detection and Differentiation of Pathogenic and Nonpathogenic Leptospira spp. by Multiplex Real-Time PCR (TaqMan) assay
}

\author{
ORHAN BEDIR ${ }^{1}$, ABDULLAH KILIC ${ }^{1 *}$, ERDINC ATABEK ${ }^{2}$, AHMET MERT KUSKUCU ${ }^{1}$, \\ VEDAT TURHAN $^{3}$ and A. CELAL BASUSTAOGLU ${ }^{1}$ \\ ${ }^{1}$ Department of Microbiology and Clinical Microbiology, Gulhane Military Medical Academy \\ and School of Medicine 06018, Ankara, Turkey \\ ${ }^{2}$ Central Veterinary Control and Research Institute, Etlik, Ankara, Turkey \\ ${ }^{3}$ Department of Infectious Diseases, Gulhane Military Medical Academy and School of Medicine, \\ Haydarpasa Training Hospital, Istanbul, Turkey
}

Received 3 August 2009, revised 1 June 2010, accepted 15 June 2010

\begin{abstract}
Leptospirosis, caused by pathogenic Leptospira, is one of the most important zoonoses in the world. Several molecular techniques have been developed for detection and differentiation between pathogenic and saprophytic Leptospira spp. The aim of this study was to develop a rapid and simple assay for specific detection and differentiation of pathogenic Leptospira spp. by multiplex real-time PCR (TaqMan) assay using primers and probes targeting Leptospira genus specific $16 \mathrm{~S}$ ribosomal RNA gene, the pathogen specific lig $A / B$ genes and nonpathogen Leptospira biflexa specific 23S ribosomal RNA gene. Sixteen reference strains of Leptospira spp. including pathogenic and nonpathogenic and ten other negative control bacterial strains were used in the study. While the 16S primers amplified target from both pathogenic and non-pathogenic leptospires, the $\operatorname{lig} A / B$ and the $23 \mathrm{~S}$ primers amplified target DNA from pathogenic and non-pathogenic leptospires, respectively. The multiplex real-time PCR (TaqMan) assay detection limit, that is, the sensitivity was found approximately $1 \times 10^{2}$ cells $/ \mathrm{ml}$ for $l i g A / B$ gene and $23 \mathrm{~S}$ ribosomal RNA gene, and 10 cells $/ \mathrm{ml} 16 \mathrm{~S}$ ribosomal RNA. The reaction efficiencies were $83-105 \%$ with decision coefficients of more than 0.99 in all multiplex assays. The multiplex real-time PCR (TaqMan) assay yielded negative results with the ten other control bacteria. In conclusion, the developed multiplex real-time PCR (TaqMan) assay is highly useful for early diagnosis and differentiation between pathogenic and non-pathogenic leptospires in a reaction tube as having high sensitivity and specificity.
\end{abstract}

K e y w o rd s: Leptospira genus, leptospirosis, multiplex real-time PCR (TaqMan) assay, pathogenic Leptospira, saprophytic Leptospira

\section{Introduction}

Leptospirosis is caused by spirochetes of the genus Leptospira (Guerra, 2009). The Leptospira genus has been classified into 17 species by DNA-DNA hybridization. This genus is further divided into three groups as pathogenic, nonpathogenic, and opportunistic/possibly pathogenic. The pathogenic leptospires include eight species: Leptospira interrogans, Leptospira kischneri, Leptospira borgpetersenii, Leptospira santarosai, Leptospira weilii, Leptospira alexanderi, Leptospira genomospecies 1 and Leptospira noguchii (Brenner et al., 1999). The Leptospira genus has also been classified on the basis of surface antigen patterns. They are divided into at least 250 serotypes that have major antigens in common and are combined into 24 serogroups (Dutta and Christopher, 2005).
Leptospirosis is identified as one of the emerging infectious diseases and a major public health concern worldwide. The organism affects virtually any mammal, including humans. Humans acquire the organisms through contact with contaminated soil, water, vegetation or with the body fluids of animals harboring leptospires (Palaniappan et al., 2005). More than 500000 severe leptospirosis cases have been reported each year around the world (WHO, 1999). The rate of leptospirosis cases varies depending on the climate and animal reservoirs. The incidence of leptospirosis is especially highest during the summer season with heavy rains and floods (Xue et al., 2008).

Since the currently available microscopic agglutination test (MAT) that is a known gold standard does not permit early diagnosis and other serologic methods have low sensitivity, more rapid and sensitive methods

* Corresponding author: A. Kilic, Department of Microbiology and Clinical Microbiology, Gulhane Military Medical Academy, School of Medicine, 06018, Ankara, Turkey; phone: (+90) 312-3043412; e-mail: abkilic@gata.edu.tr 
are needed for detection of Leptospira as well as the ability to distinguish pathogenic and nonpathogenic Leptospira. Therefore, a number of molecular methods such as conventional multiplex PCR (Kositanont et al., 2007), real-time PCR (Slack et al., 2007; Levett et al., 2005), nested-PCR (Bomfim et al., 2008), loop mediated isothermal amplification (LAMP) (Lin et al., 2009), nested PCR-restriction fragment length polymorphism (RFLP) (Djadid et al., 2009) have been developed for specific detection of pathogenic Leptospira spp. in diagnostic laboratories. The TaqMan real-time PCR method has also been used for detection of pathogenic Leptospira spp. based on specific target sequences including the ribosomal $16 \mathrm{~S}$ ribosomal RNA gene, and the Leptospira immunoglobulin-like protein $\mathrm{A}$ and $\mathrm{B}$ gene (lig $A$ and $\operatorname{lig} B$ ) (Palaniappan 2005). The $\operatorname{lig} A$ and $\operatorname{lig} B$ genes encode amino-terminal lipoprotein signal peptides followed by 10 or 11 big domain repeats. The lig genes are only detected in pathogenic Leptospira spp. as a unique virulence factor. Conversely, these genes are not found in nonpathogenic Leptospira spp. (Matsunaga et al., 2003).

The aim of this study was to develop a rapid and simple assay for the specific detection and differentiation of pathogenic Leptospira spp. by multiplex real-time PCR TaqMan method using primers and probes specific for Leptospira genus 16S ribosomal RNA gene, pathogen specific lig $A / B$ genes and nonpathogen Leptospira biflexa specific $23 \mathrm{~S}$ ribosomal RNA gene.

\section{Experimental}

\section{Materials and Methods}

Leptospira reference strains and control bacterial strains. Sixteen reference strains of Leptospira spp. including pathogenic and nonpathogenic were obtained from the Etlik Central Veterinary Control and Research Institute (ECVCRI), WHO Collaborating Center, Ankara, Turkey (Table I). All strains were stored in Fletcher media (Difco, Detroit, MI, USA) and then cultured in liquid Ellinghausen McCullough Johnson Harris (EMJH) (Difco) media supplemented with $10 \%$ serum of hemolysed rabbit blood at $30^{\circ} \mathrm{C}$ for 7 days. Other control bacterial strains including Escherichia coli ATCC 35218, Pseudomonas aeruginosa ATCC 27853, Klebsiella pneumoniae ATCC 13883, Staphylococcus aureus ATCC 25923, Enterococcus faecalis ATCC 27270, Salmonella typhimurium NCTC 12023, Legionella pneumophila, Neisseria gonorrhoeae NCTC 8375, Borrelia burgdorferi strain B31, and Streptococcus pyogenes NCTC 12696 were selected from stock reference culture collection in our laboratory. The isolates were stored at $-70^{\circ} \mathrm{C}$ in trypticase soy broth (Merck, Darmstadt, Germany) supplemented with $15 \%$ glycerol before being tested.

Design of primers and probes. Oligonucleotide primers and probes for multiplex real-time PCR (TaqMan) assay were designed based on a particular region of the $\operatorname{lig} A / B$ gene sequence (lig $A / B-\mathrm{P} 1-5$ 'cggttc tcacttctattcaa-3', lig $A / B-\mathrm{P} 2-5$ ' -attgaagaatcggat gagaa-3', and ligA/B-Probe-Texas red-5'-atcctgtaaa tcctt ctcttgcaaa-3'-Bhq-2) for pathogenic Leptospira spp. (Genbank accession nos FJ030916, EF517920, AF534640, AF368236, and AY221109), the 16S ribosomal RNA gene sequence (16S-P1-5'-tagtgaacgg gatagatac-3', 16S-P2-5'-ggtctacttaatccgttagg-3', and 16S-Prob-Fam-5'-aatccacgcctaaacgttgtctac-3'-Bhq-1) for Leptospira spp. genus (Genbank accession nos FJ154560, FJ154600, FJ154577, FJ154571, FJ154569, FJ154568, FJ154564, FJ154563, FJ154556, FJ154555, and FJ154553), and the 23S ribosomal RNA gene sequence (23S-P1-5' -acaatcttaccaaacctatc-3', 23SP2-5'-ttaccacttagcgtagattt-3', and 23S-Prob-Joe-5'tccgaatactgtaacttgaagtactgca-3'-Bhq-1) for non-pathogenic L. biflexa (Genbank accession no CP000786) by using oligo analysis and design program Oligaware 3.0 developed in our institution (Table II). BLAST program was used to initially asses the ability of the primers and probes to identify target sequences (Smythe et al., 2002; Altschul et al., 1997). The primers and probes were synthesized by Metabion International, Germany.

DNA extraction. DNA was extracted from the samples by treatment with $1 \%$ SDS and $100 \mathrm{mg}$ proteinase K (Sigma Chemicals, St. Louis, Missouri, USA) in a buffer containing $50 \mathrm{mM}$ Tris ( $\mathrm{pH} \mathrm{8.0)}$, $50 \mathrm{mM}$ EDTA, $100 \mu \mathrm{M} \mathrm{NaCl}$. After 2 hours of incubation at $55^{\circ} \mathrm{C}$ in a waterbath, the DNA was purified by repeated extraction with phenol/chloroform/isoamyl alcohol $(25: 24: 1)$. The DNA was concentrated by precipitation with $99 \%$ ethanol. The precipitate was collected by centrifugation, then dried and resuspended in deioinized sterile water (Veloso et al., 2000).

Multiplex real-time PCR (TaqMan). The multiplex real-time PCR (TaqMan) method was performed by using a 7500 ABI Prism Sequence Detector (Applied Biosystems, Foster City, Calif., USA). In brief, $2 \mathrm{ml}$ of the extracted nucleic acid solution was added to $23 \mu \mathrm{l}$ of reaction mixture containing $0.8 \mu \mathrm{M}$ of each primer and $0.4 \mu \mathrm{M}$ each fluorophore probe (final concentration), and mixed with $12,5 \mu \mathrm{l}$ of TaqMan Universal PCR Master Mix (Applied Biosystems). The TaqMan cycling conditions included a 10 min degradation of the preamplified templates at $95^{\circ} \mathrm{C}$ and then 40 cycles of denaturation at $95^{\circ} \mathrm{C}$ for $15 \mathrm{~s}$ and annealing and extension at $60^{\circ} \mathrm{C}$ for $60 \mathrm{~s}$. All experiments were repeated at least twice for testing the reproducibility of the assay.

Detection limits determination and assay validation. Pathogenic L. interrogans strain Wijnberg and 
Table I

Leptospira strains used in this study

\begin{tabular}{|l|l|l|}
\hline \multicolumn{1}{|c|}{ Genomospecies } & \multicolumn{1}{c|}{ Serovar } & \multicolumn{1}{c|}{ Strain } \\
\hline Leptospira interrogans & australis & Ballico \\
\hline Leptospira interrogans & autumnalis & Akiyami A \\
\hline Leptospira interrogans & bataviae & Swart \\
\hline Leptospira interrogans & bratislava & Jes Bratislava \\
\hline Leptospira interrogans & hebdomadis & Hebdomadis \\
\hline Leptospira interrogans & icterohaemorrhagiae & Wijnberg \\
\hline Leptospira interrogans & hardjo & Hardjoprajitno \\
\hline Leptospira. interrogans & canicola & Hond Utrecht IV \\
\hline Leptospira interrogans & icterohaemorrhagiae & RGA \\
\hline Leptospira interrogans & pomona & Pomona \\
\hline Leptospira interrogans & pyrogenes & Salinem \\
\hline Leptospira borgpetersenii & ballum & Mus 127 \\
\hline Leptospira borgpetersenii & javanica & Veldrat Batavia 46 \\
\hline Leptospira borgpetersenii & tarassovi & Perepelitsin \\
\hline Leptospira kirschneri & grippotyphosa & Moskova V \\
\hline Leptospira biflexa & patoc & Patoc I \\
\hline
\end{tabular}

Table II

Oligonucleotide sequence of the primers and probes used in this study

\begin{tabular}{|c|c|c|c|}
\hline Target region & Oligo Name & Sequence $\left(5^{\prime}-3^{\prime}\right)$ & Genbank accession no \\
\hline \multirow{3}{*}{$\begin{array}{l}\text { ligA/B gene for pathogenic } \\
\text { Leptospira spp. }\end{array}$} & $\operatorname{lig} A / B-\mathrm{P} 1$ (Forward) & 5'-cggttctcacttctattcaa-3' & \multirow{3}{*}{$\begin{array}{l}\text { FJ030916, EF517920, AF534640, } \\
\text { AF368236, and AY221109 }\end{array}$} \\
\hline & $\operatorname{lig} A / B-\mathrm{P} 2$ (Reverse) & 5'-attgaagaatcggatgagaa-3' & \\
\hline & lig $A / B$-Prob & $\begin{array}{l}\text { Texas Red-5' } \\
\text {-atcctgtaaatccttctcttgcaaa-3'-Bhq-2 }\end{array}$ & \\
\hline \multirow{3}{*}{$\begin{array}{l}\text { 23S rRNA gene for non- } \\
\text { pathogenic Leptospira spp. }\end{array}$} & 23S-P1 (Forward) & 5'-acaatcttaccaaaccctatc-3' & \multirow[t]{3}{*}{ СР000786 } \\
\hline & 23S-P2(Reverse) & 5'-ttaccacttagcgtagattt-3' & \\
\hline & 23S-Prob & Joe-5'-tccgaatactgtaacttgaagtactgca-3-Bhq-1 & \\
\hline \multirow{3}{*}{$\begin{array}{l}\text { 16S rRNA gene } \\
\text { for Leptospira genus }\end{array}$} & 16S-P1(Forward) & 5'-tagtgaacgggattagatac-3', & \multirow{3}{*}{$\begin{array}{l}\text { FJ154560, FJ154600, FJ154577, } \\
\text { FJ154571, FJ154569, FJ154568, } \\
\text { FJ154564, FJ154563, FJ154556, } \\
\text { FJ154555, and FJ154553 }\end{array}$} \\
\hline & 16S-P2 (Reverse) & 5'-ggtctacttaatccgttagg-3', & \\
\hline & 16S-Prob & Fam-5'-aatccacgccctaaacgttgtctac-3'-Bhq-1 & \\
\hline
\end{tabular}

L. biflexa strain Patoc I were cultured in EMJH (Difco) media to obtain a cell density of $1 \times 10^{8} \mathrm{cells} / \mathrm{ml}$ for each of the target species, and then total DNA was extracted. Serial 10-fold dilutions of extracted DNA were prepared ranging from $1 \times 10^{6}$ cells $/ \mathrm{ml}$ to $1 \times 10^{0}$ cells $/ \mathrm{ml}$ by using sterile $\mathrm{ddH} 2 \mathrm{O}$. The threshold cycle $(\mathrm{Ct})$ value of each dilution was recorded. The lowest number of leptospires detected visually was defined as the detection limit of the assay.

\section{Results}

Multiplex real-time (TaqMan) PCR assay using $\operatorname{Lig} \mathrm{A} / \mathrm{B}, 16 \mathrm{~S}$, and $23 \mathrm{~S}$ primers and probes. The sixteen standard strains of Lepotospira spp. were tested for all genes. The multiplex real-time PCR (TaqMan) assay was used to amplify specific leptosiral sequences including $l i g A / B$ genes, 16S ribosomal RNA gene and
23S ribosomal RNA gene simultaneously in a single tube. The lig $A / B$ primers and probe designed based on particular region of $\operatorname{lig} A / B$ of pathogenic leptospires gave a detectable product, $\mathrm{Ct}$ values ranged from 17 to 39 and averaged 24 for only all pathogenic leptospires, whereas the $23 \mathrm{~S}$ primers and probe designed based on the particular region of $23 \mathrm{~S}$ ribosomal RNA non-pathogenic leptospires gave a detectable product $\mathrm{Ct}$ values ranged from 18 to 36 and averaged 23 for only nonpathogenic leptospires. The $16 \mathrm{~S}$ primers and probe designed from the conserved region of $16 \mathrm{~S}$ ribosomal RNA of Leptospira genus amplified genomic DNA from both pathogenic and non-pathogenic leptospires.

Sensitivity and specificity of multiplex real-time PCR (TaqMan) method. The reaction efficiency of each assay was counted from the slopes of standard curves. The reaction efficiencies were found to be $83-105 \%$ with decision coefficients of more than 0.99 in all multiplex assays. To determine assay sensitivity, 


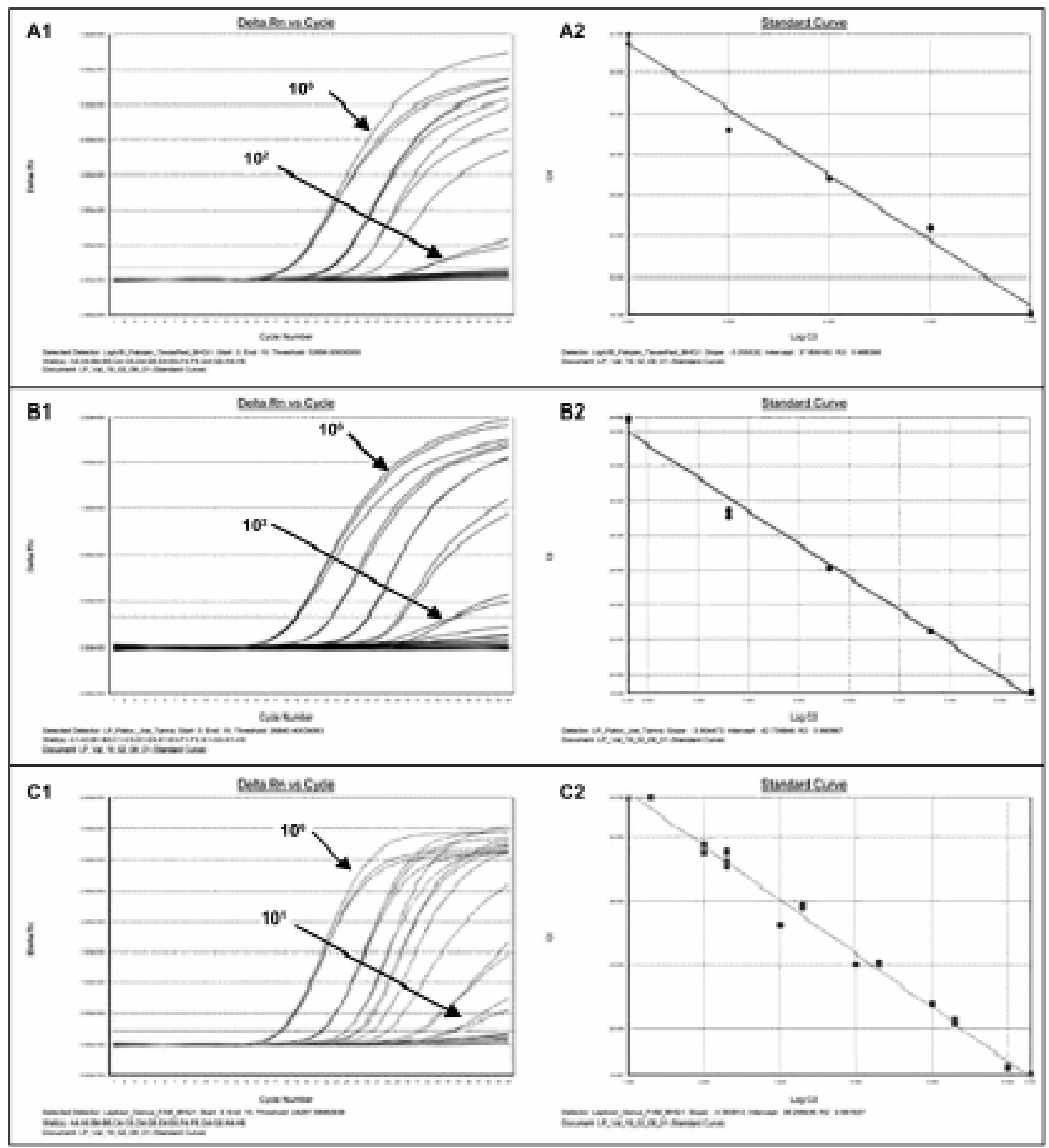

Fig. 1. Amplification curves and dilution end point standard curves of $\log 10$ genome equivalents versus CT cycle number. The analytical sensitivity of this assay for ligA/B (A1-A2) and 23S ribosomal RNA (B1-B2) assays were approximately 100 genome per $\mathrm{ml}$ and $16 \mathrm{~S}$ rRNA $(\mathrm{C} 1-\mathrm{C} 2)$ assay was approximately 10 genome equivalents per $\mathrm{ml}$.

Leptospiral DNA was adjusted by 10 -fold serial dilution ranging from $1 \times 10^{6} \mathrm{cell} / \mathrm{ml}$ to $1 \times 10^{0} \mathrm{cells} / \mathrm{ml}$ from both pathogenic Leptospira interrogans strain Wijnberg and Leptospira biflexa strain Patoc I. Linear dynamic range of multiplex real-time PCR (TaqMan) assay was performed with triplicates of 10 -fold dilutions of the purified genomic DNA extracted from pathogenic and nonpathogenic leptospires, and was observed constantly (Fig. 1). The standard curves obtained with 10-fold serially diluted genomic DNA preparations were linear over seven orders of magnitude for targeting sequence. The assay detection limit, that is the sensitivity, was found to be approximately $1 \times 10^{2}$ cells $/ \mathrm{ml}$ for $\operatorname{lig} A / B$ gene and $23 \mathrm{~S}$ ribosomal RNA gene, and 10 cells $/ \mathrm{ml} 16 \mathrm{~S}$ ribosomal RNA. To determine the assay specificity of multiplex real-time PCR (TaqMan) assay, other control bacteria were tested with $\operatorname{lig} A / B, 23 \mathrm{~S}$ and $16 \mathrm{~S}$ primer and probes. The multiplex real-time PCR (TaqMan) assay yielded negative results with the ten other control bacteria. The $\operatorname{lig} A / B$, the $16 \mathrm{~S}$, and $23 \mathrm{~S}$ primers and probes were specific for pathogenic leptospires, Leptspira genus, and nonpathogenic leptospira, respectively (Fig. 2).

\section{Discussion}

Leptospirosis is known to be an emerging zoonotic disease caused by the genus Leptospira worldwide (Guerra, 2009). Since there is no national Leptospira 


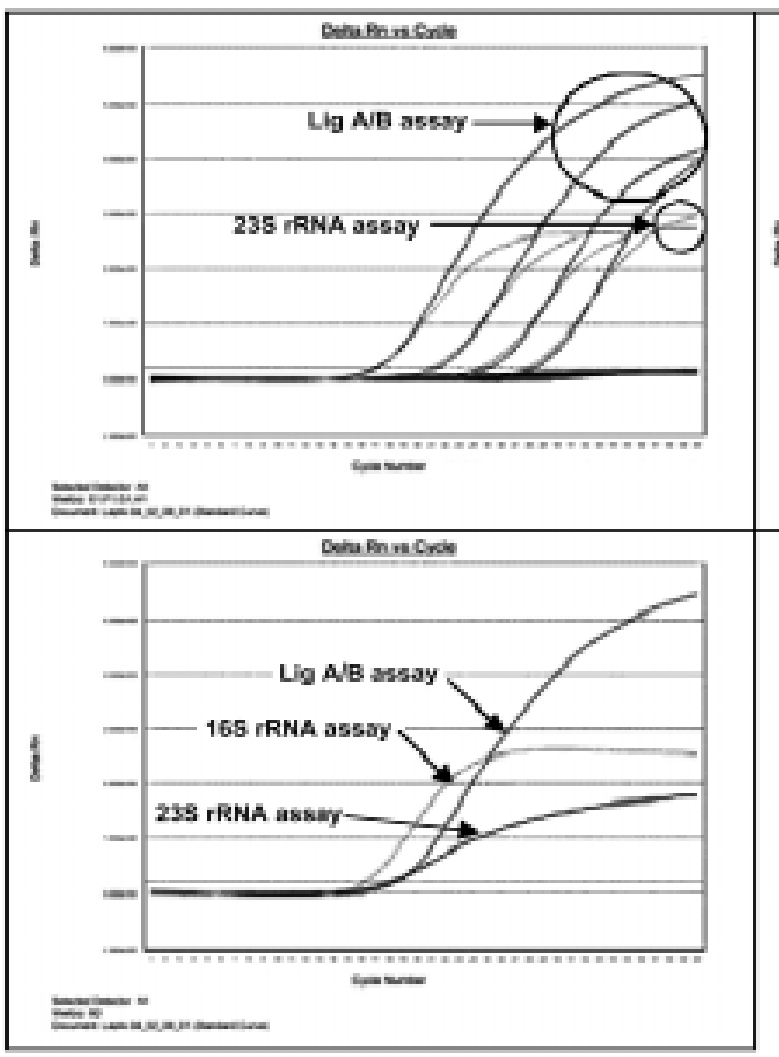

reference center in Turkey, reliable data about the incidence of leptospirosis are not available. Twelve Turkish cases were reported from south region of Turkey in 1997 (Saltoglu et al., 1997). In 2005, three cases of anicteric leptospirosis with mild and sever complications, a case of icteric leptospirosis with resistant immune hemolytic anemia, and four cases of anicteric leptospirosis with mania and psychosis were reported from the central Anatolia and northwest region of Turkey (Erdinc et al., 2006; Solmazgul et al., 2005; Semiz et al., 2005). Recently a Turkish leptospirosis case complicated with cerebral venous thrombosis was reported from the northwest region of Turkey (Turhan et al., 2006).

A spectrum of human leptospirosis is recognized ranging from subclinical infection to a severe syndrome of multiorgan infection such as severe vasculitis and intravascular coagulation (Guerra, 2009). However, the symptoms of leptospirosis at the prodromal stage are almost indistinguishable from various other bacterial and viral febrile infections such as salmonellosis and dengue virus infection (Srimanote et al., 2008). In addition, the lack of reliable techniques for rapid diagnosis of leptospirosis may cause delay in treatment of patients and lethal sequela (Djadid et al., 2009). In diagnosis of leptospirosis, serological methods such as MAT and enzyme-linked immunosorbent assay (ELISA) based on the immunogenic response of the host and culture method to observe the organisms from clinical samples are usually per-

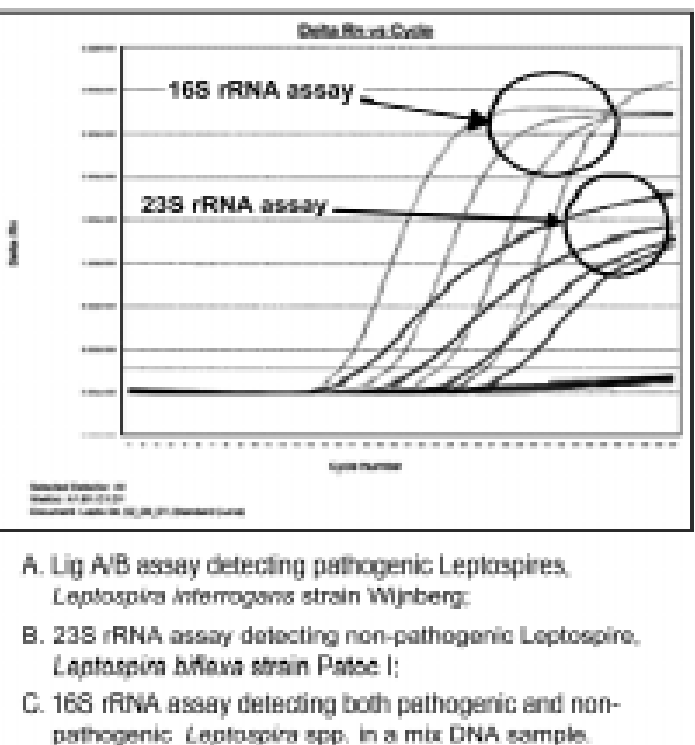

Fig. 2. Multiplex amplification results with Leptospira interrogans strain Wijnberg, Leptospira biflexa strain Patoc I and mix DNA samples. In 10 fold dilutions 4 times.

formed in many laboratories. MAT is used to detect leptospiral antibody from the patient sera using live organisms as sources of antigens. Since antileptospiral antibody becomes detectable only after 8-10 days from the onset of illness, MAT cannot provide early diagnosis of leptospirosis (Smythe et al., 2002). In addition to MAT, other serologic tests detecting leptospires from clinical samples are not appreciable, especially during the early phase of the infection (Palaniappan et al., 2005; Srimanote et al., 2008). Leptospira is a fastidious microorganism and difficult to grow in culture medium. Moreover, culture which requires a special medium and at least two weeks to yield the organisms, cannot provide an early diagnosis. Thus, these techniques are used mainly for epidemiological purposes (Palaniappan et al., 2005; Srimanote et al., 2008). Therefore, there is a need for a reliable and accurate method for detection and differentiation of leptospires from clinical samples. The multiplex realtime PCR (TaqMan) assay is a rapid, sensitive and specific assay for detection of leptospires during early stage of infection (Palaniappan et al., 2005; Smythe et al., 2002; Slack et al., 2006). This assay has also been used as a diagnostic tool for the discrimination of pathogenic and non-pathogenic leptospires using particular gene sequence (Smythe et al., 2002).

In this study, we developed a multiplex real-time PCR (TaqMan) assay to detect infection and the same time distinguish pathogenic leptospires from nonpathogenic leptospires in same reaction tube. The 
lig $A / B, 23 \mathrm{~S}, 16 \mathrm{~S}$ primers and probes were used for specific detection of pathogenic, non-pathogenic leptospires and leptospira genus. This assay was able to detect rapidly leptospira genus and distinguish pathogenic leptospires from non-pathogenic ones. The detection limit of the assay was 100 leptospira cells/ml for pathogenic, non-pathogenic leptospires, and $10 \mathrm{cells} / \mathrm{ml}$ for leptospira genus. While the $16 \mathrm{~S}$ primers amplified the target from both pathogenic and non-pathogenic leptospires, lig $A / B$ amplified target DNA only from pathogenic leptospires and the $23 \mathrm{~S}$ primers were specific for non-pathogenic ones. Thus, this assay may enable the recognition and discrimination between pathogenic and non-pathogenic, environmental contaminant leptospires in the same reaction tube.

A number of gene sequences have been used to detect and distinguish pathogenic leptospires from non-pathogenic ones. Woo et al. developed a realtime PCR (TaqMan) method using 23S rRNA gene sequence for identification of pathogenic Leptospira (Woo et al., 1996). Levett et al. evaluated a highly sensitive and specific real-time PCR (TaqMan) method for lipL32 gene, which is a probable virulence gene, for detection of pathogenic leptospires (Levett et al., 2005). Slack et al. used DNA gyrase subunit B gene for identification of pathogenic Leptospira spp. When compared to the 16S rRNA gene, the gyrB gene showed greater nucleotide/evolutionary divergence allowing superior identification (Slack et al., 2006). Kawabata et al. used flab gene and suggested that PCR-RFLP was an efficient tool for rapid detection and identification of species of Leptospira from clinical specimens (Kawabata et al., 2001). Djadid et al. developed a nested PCR-RFLP assay using 16S rRNA as a rapid and specific available technique for differentiate pathogenic and non-pathogenic Leptospira spp. in the early stage of infection (Djadid et al., 2009). In this study, the $\operatorname{lig} A / B$ primers were used in a multiplex real-time (TaqMan) PCR assay to detect and distinguish pathogenic Leptospira serovar. The lig genes encode surface proteins containing immunoglobulin-like repeat predicted to play a role in adhesion to host tissues. Previous studies have demonstrated that pathogenic leptospires contain these genes, while they are absent from the non-pathogenic saprophyte (Xue et al., 2008). Diagnostic methods such as PCR and ELISA targeting lig genes have been recently developed to discrimination pathogenic and non-pathogenic leptospires (Palaniappan et al., 2005; Srimanote et al., 2008). Palaniappan et al. developed a real-time PCR (TaqMan) assay using lig1/lig2 primers targeting the conserved region of $\operatorname{lig} A$ and $B$ as a sensitive and rapid tool for early diagnosis of leptospirosis (Palaniappan et al., 2005). One of the most significant advantages of our multiplex real-time PCR (TaqMan) assay is that both pathogenic and non-patho- genic leptospires were detected at the same cycling conditions allowing all three reactions to be performed in a single PCR tube simultaneously. We also analyzed leptospires based on the genus in the same reaction tube as an internal control. To our knowledge, this is the first study detecting three leptospire gene sequences in the same reaction tube. The efficiency of each assay ranged between 83 and 105\%; the accepted ranges for PCR efficiency are generally between 80.0 and $110.0 \%$.

In conclusion, the developed multiplex real-time PCR (TaqMan) assay targeting lig $A / B$ gene, $16 \mathrm{~S}$ ribosomal RNA and 23S ribosomal RNA sequences is highly useful for early diagnosis of leptospirosis and differentiation between pathogenic and non-pathogenic leptospires in the same reaction tube with high sensitivity and specificity.

\section{Literature}

Altschul S.F., T.L. Madden, A.A. Schäffer, J. Zhang, Z. Zhang, W. Miller and D.J. Lipman. 1997. Gapped BLAST and PSIBLAST: a new generation of protein database search programs. Nucleic Acids Res. 25: 3389-3402.

Bomfim M.R., E.F. Barbosa-Stancioli and M.C. Koury. 2008 Detection of pathogenic leptospires in urine from naturally infected cattle by nested PCR. Vet. J. 178: 251-256.

Brenner D.J., A.F. Kaufmann, K.R. Sulzer, A.G. Steigerwalt, F.C. Rogers and R.S. Weyant. 1999. Further determination of DNA relatedness between serogroups and serovars in the family Leptospiraceae with a proposal for Leptospira alexanderi sp. nov. and four new Leptospira genomospecies. Int. J. Syst. Bacteriol. 49: 839-858.

Djadid N.D., Z.F. Ganji, M.M. Gouya, M. Rezvani and S. Zakeri. 2009. A simple and rapid nested polymerase chain reaction-restriction fragment length polymorphism technique for differentiation of pathogenic and nonpathogenic Leptospira spp. Diagn. Microbiol. Infect. Dis. 63: 251-256.

Dutta T.K. and M. Christopher. 2005. Leptospirosis-an overview. J. Assoc. Physicians India 53: 545-551.

Erdinc F.S., S.T. Koruk, C.A. Hatipoglu, S. Kinikli and A.P. Demiroz. 2006. Three cases of anicteric leptospirosis from Turkey: mild to severe complications. J. Infect. 52: 45-48.

Guerra M.A. 2009. Leptospirosis. J. Am. Vet. Med. Assoc. 234: 472-478.

Kawabata H., L.A. Dancel, S.Y. Villanueva, Y. Yanagihara, N. Koizumi and H. Watanabe. 2001. flaB-polymerase chain reaction (flaB-PCR) and its restriction fragment length polymorphism (RFLP) analysis are an efficient tool for detection and identification of Leptospira spp. Microbiol. Immunol. 45: 491-496.

Kositanont U., S. Rugsasuk, A. Leelaporn, D. Phulsuksombati, S. Tantitanawat and P. Naigowit. 2007. Detection and differentiation between pathogenic and saprophytic Leptospira spp. by multiplex polymerase chain reaction. Diagn. Microbiol. Infect. Dis. 57: 117-122.

Levett P.N., R.E. Morey, R.L. Galloway, D.E. Turner, AG. Steigerwalt and L.W. Mayer. 2005. Detection of pathogenic leptospires by real-time quantitative PCR. J. Med. Microbiol. 54: 45-49.

Lin X., Y. Chen, Y. Lu, J. Yan and J. Yan. 2009. Application of a loop-mediated isothermal amplification method for 
the detection of pathogenic Leptospira. Diagn. Microbiol. Infect. Dis. 63: 237-42.

Matsunaga J., M.A. Barocchi, J. Croda, T.A. Young, Y. Sanchez, I. Siqueira, C.A. Bolin, M.G. Reis, L.W. Riley, D.A. Haake and A.I. Ko. 2003. Pathogenic Leptospira species express surface-exposed proteins belonging to the bacterial immunoglobulin superfamily. Mol. Microbiol. 49. 929-945.

Palaniappan R.U., Y.F., Chang, C.F., Chang, M.J., Pan, C.W. Yang, P. Harpending, S.P. McDonough, E. Dubovi, T. Divers, J. Qu and B. Roe. 2005. Evaluation of lig-based conventional and real time PCR for the detection of pathogenic leptospires. Mol. Cell. Probes. 19: 111-117.

Saltoglu N., H.Z. Aksu, Y. Tasova, A. Arslan, A. Canataroğlu, I.H. Dündar and F. Köksal. 1997. Leptospirosis: twelve Turkish patients with the Weil syndrome. Acta. Med. Okayama. 51: 339-342.

Semiz U.B., V. Turhan, C. Basoglu, O. Oner, S. Ebrinc and M. Cetin. 2005. Leptospirosis presenting with mania and psychosis: four consecutive cases seen in a military hospital in Turkey. Int. J. Psychiatry Med. 35: 299-305.

Slack A.T., M.L. Symonds, M.F. Dohnt and L.D. Smythe. 2006. Identification of pathogenic Leptospira species by conventional or real-time PCR and sequencing of the DNA gyrase subunit B encoding gene. B.M.C. Microbiol. 6: 95.

Slack A., M. Symonds, M. Dohnt, C. Harris, D. Brookes and L. Smythe. 2007. Evaluation of a modified Taqman assay detecting pathogenic Leptospira spp. against culture and Leptospiraspecific IgM enzyme-linked immunosorbent assay in a clinical environment. Diagn. Microbiol. Infect. Dis, 57: 361-366.
Smythe L.D., I.L. Smith, G.A. Smith, M.F. Dohnt, M.L. Symonds, L.J. Barnett and D.B. McKay. 2002. A quantitative PCR (TaqMan) assay for pathogenic Leptospira spp. B.M.C. Infect. Dis. 2: 13.

Solmazgul E., V. Turhan, S. Unver, M.Demirci, S. Nalbant and M. Danaci. 2005. A case of Weil's syndrome developing steroid resistant immune haemolytic anaemia. Scand. J. Infect. Dis. 37: 700-702.

Srimanote P., N. Wongdeethai, P. Jieanampunkul, S. Samonkiert, C. Leepiyasakulchai, T. Kalambaheti and V. Prachayasittikul. 2008. Recombinant ligA for leptospirosis diagnosis and ligA among the Leptospira spp. clinical isolates. J. Microbiol. Methods. 72: 73-81.

Turhan V., M.G, Senol, G. Sonmez, O. Oncul, S. Cavuslu and O. Tanridag. 2006. Cerebral venous thrombosis as a complication of leptospirosis. J. Infect. 53: 247-249.

Veloso I.F., M.T. Lopes, C.E. Salas and E.C. Moreira. 2000 A comparison of three DNA extractive procedures with Leptospira for polymerase chain reaction analysis. Mem. Inst. Oswaldo. Cruz. 95: 339-343.

Woo T.H., L.D. Smythe, M.L. Symonds, M.A. Norris, M.F. Dohnt and B.K. Patel. 1996. Rapid distinction between Leptonema and Leptospira by PCR amplification of 16S-23S ribosomal DNA spacer. FEMS Microbiol. Lett. 142: 85-90.

World Health Organization. 1999. Leptospirosis worldwide. Weekly Epidemiol. Rec. 74: 237-242.

Xue F., J. Yan and M. Picardeau. 2008. Evolution and pathogenesis of Leptospira spp.: lessons learned from the genomes. Microbes. Infect. 11: 328-333. 